\title{
Leveraging Brand Equity by Applying Brand Communication and Forming City Branding Based on Unique Selling Proposition (A Case of Crafts City)
}

\author{
Hidayat Asep Tarman* \\ Economic Faculty, Siliwangi \\ University, Tasikmalaya, Indonesia \\ Arisman Ari \\ Economic Faculty, Perjuangan \\ University, Tasikmalaya, Indonesia
}

\author{
Soeaidy Mohammad Soleh \\ Economic Faculty, Siliwangi \\ University, Tasikmalaya, Indonesia \\ Taufiq Adhitya Rahmat \\ Economic Faculty, Siliwangi \\ University, Tasikmalaya, Indonesia
}

\begin{abstract}
The purpose of this study is to find out how the influence of a unique selling proposition on brand communication and city branding will build brand equity for a city. This research uses descriptive empiric. The survey was conducted in Tasikmalaya with the number of samples is 265 respondent whom they are the origin of this city, or, at least, have been dwelling in this city for about two years, by using purposive sampling. The analysis used for this research is Structural Equation Modelling (SEM), where it needs to examine the influence between the Unique Selling Proposition towards Brand Communication, City Branding, and Branding Equity. The result of this research shows that the Unique Selling Proposition influences Brand Communication and City Branding. Thus, the better unique selling proposition will increase brand communication and build good city branding as the City of Crafts. Moreover, the unique selling proposition did not influence brand equity. Thus, it still can not build brand equity because of the uniqueness in the proportion of sales is not communicated, it will not make the stakeholders aware that they will not even make it loyal. The results also proved a strong influence between city branding towards brand equity so that it can be concluded that good city branding will make brand equity better. This research's originality is by observing brand equity from a city through city branding with a unique selling proposition approach.
\end{abstract}

Keywords: Brand communication, brand equity, city branding, unique selling proposition

Received: 02 January 2019; Accepted: 12 March 2019; Published: 26 April 2019

\section{INTRODUCTION}

The era of globalization has made cities in the world have to compete with each other. This competition is conducted to attract attention, influence, market, business \& investment goals, tourists, residents, skilled labor, and also organizers of various events in various fields (Van Gelder, 2008). Cities, economics, and culture, increasingly become the focus of international competition to get funding, talent, and fame. It is important for city political and business leaders to understand their brands better, and to see how a city is seen by prospective visitors, investors, customers, and future citizens throughout the world (Anholt, 2006). Places, including countries and cities, have begun to implement branding strategies to improve their position as tourist destinations and attract targeted immigrants. A brand that provides

\footnotetext{
${ }^{*}$ Correspondence concerning this article should be addressed to Hidayat Asep Tarman, Economic Faculty, Siliwangi University, Tasikmalaya, Indonesia. E-mail: aseptarmanhidayat.ath@gmail.com

(C) 2019 The Author(s). Published by KKG Publications. This is an Open Access article distributed under a Creative Commons AttributionNonCommercial-NoDerivatives 4.0 International License.
} 
economic value is determined by the existence of brand equity (Chan, 2014; Eze, 2017).

The attention of cities is focused on place branding because they are important resources in attracting creative classes, labor and visitors (Dinnie, 2010), which ultimately directs their respective countries to become rich and prosperous. City branding is the right way to describe and implement city marketing. In developing city marketing, it is necessary to develop an awareness that the functioning of cities effectively depends on creating a new set of policies that can combine markets, both internal and external, into urban planning and management (Ashworth \& Voogd, 1988; Wichailert \& Yousapornpaiboon, 2017).

The construction, communication, and management of city image are the application of city marketing, which is the image of the city is the object on city marketing. The starting point is developing the branding of the city. The most appropriate concept for understanding the application of marketing in cities is the concept of branding in companies that are modified and applied to cities (Kavaratzis, 2004). The purpose of branding is to add value to products, services, or organizations. When translated into place, the purpose of branding is to add value to the intended place in a broad sense. By influencing the perceived quality of the place in question, branding a place can indirectly generate more tourist attraction, more people, more companies, and more investment, but the core of branding places must add value to people who are in that place (Boisen, Terlouw, \& van Gorp, 2011; Hung \& Chen, 2017; Oetomo \& Budiyanto, 2017).

Competition between cities now requires cities to be unique and have differences. To win the competition, cities must have a Unique Selling Proposition strategy. The unique selling point of the entire product or part of the product from different places and brings a unique position to this place on the market. Unique selling features can be understood as competitive advantages, which means, that is special and unique, which distinguishes the place from its competitors (Borseková, Vaňová, \& Petríková, 2015). Which represents value for the customers of the place is a competitive advantage that has special, unique, and exceptional quality, ability or characteristic (Borseková et al., 2015). The place needs to be distinguished through a unique brand identity if it is to, be recognized as existing, it is considered in the mind of the customer that the place has superior quality than the competitor, and is consumed in a way commensurate with the purpose of the place (Kavaratzis \& Ashworth, 2005). In relation to place branding, to make the brand distinctive, that is by highlighting the unique selling proposition that will distinguish brands from other brands (Elegbe \& Adesanoye, 2017).

Indonesia has many potential resources in its every region and city. Many cities have a potential creative industry that has its own characteristics, especially related to the craft industry. The availability of diverse crafts makes this city unique and different so that it can build a place branding with what it has. Every city must have its own identity or brand that can be a sign for the city. A strategic city branding is required by every city that has potential characteristics to improve the city's finances. During this time, Tasikmalaya, which is in West Java, is quite rich with variety and the best products, superior MSMEs, and natural resources. To make the city's craft a good and well-known brand and its identity, a strong culture and creativity are needed in developing the city's image. Cultural and creative activities generate economic value, become profitable, and ultimately represent the urban economic sector Sacoo, as cited in (Richards, 2014).

In marketing, the city needs to communicate the image of the city to stakeholders so that it is widely known. Kavaratzis (2004) states, city branding, is suggested as an appropriate way to describe and implement city marketing. The city marketing application is highly dependent on construction, communication, and city image management. Here, the city must communicate it as a craft city so that strong city branding can be created. With the uniqueness of the city in crafting, they can be communicated, promoted and introduced to all regions and others; citizens, travelers, foreign tourists, and investors to make their investments in the cities. City branding demands to associate a place with a story about the place, not just adding a word next to the city name or applying it only with beautiful pictures of the place. Stories must be built in that place and then communicated to all audiences (Kavaratzis, 2004).

\section{LITERATURE REVIEW}

A business requires a Unique Selling Proposition to be different from competitors. Reeves as cited in (Nasution \& Ardin, 2010) has stated, "Every advertisement must make a proposition to consumers." It's not just words, not just product peculiarities, not just displaying window ads. Each ad must tell each reader: "Buy this product, and you will get this specific benefit." The proposition must be an offer that cannot be offered or not by a competitor. This must be unique - whether it's the brand's uniqueness of the brand or claims not made in certain advertising fields. The proposition must be strong to move millions of people and attract new customers. Niu and Wang (2016), had updated 
the USP concept of Reeves because it has limitations such as its shortcomings. They agree that statements as indicators of USPs are favorability, believability, distinctiveness, compatibility, and attractiveness.

The high or low level of USP characteristics in advertisements is associated with advertising effectiveness measures with high levels of USP, compared to low USP levels, which will result in a high level of ad recognition, message comprehension, persuasion effects, attitudes toward advertising, and brand attitudes (Niu \& Wang, 2016). Successful USPs may have the power to influence word of mouth communication and attract new consumers to product offerings. Advertising campaigns that use effective and extraordinary and unique selling propositions can be a great driving force in building successful businesses (Olajide \& Abubakri, 2012). In his research, advertising is one of the great activities in Communication that must be done with a man long ago. Therefore, it can be concluded that USP can build brand communication.

Initially, the USP Theory was created for the corporate environment but can also be relatively easy to apply to conditions in places such as cities or regions. The unique selling point of the entire place of product or product is partly from a place that is different from other competitors and carries a unique position for this place in the market (Borseková et al., 2015). Many goals promote similar attributes, such as scenery, history, and culture. However, effective goal branding requires a unique sales proposition that is sustainable, trustworthy, and relevant and that "the competitor wants and may be able to copy but which he or she cannot surpass." The conclusion is that there is a unique sales proposition from a place, be it a tourist destination, a city or a country that will increase place branding Morgan, Pritchard, and Piggott, as cited in (Blain, Levy, \& Ritchie, 2005).

\section{H1: USP has an influence on Brand Communication.}

H2: USP has an influence on City Branding.

Brand communication is when ideas or images of a product or service are marketed so that specificities are identified and recognized by many consumers Jonas and Kim as cited in (Kuada, 2016). The purpose of brand communication is to expose the audience to a brand, where the effect is maximized in term increasing awareness and higher memory, so customers will buy brands that have the highest memory; and to satisfy customers to the optimal level (Zehir, Şahin, Kitapç1, \& Özşahin, 2011). Brand communication includes brand strategy, which means brand management as an activity to manage the elements that aim to create a brand. Brand communication has a definition as "whether a customer's evaluation of a brand is good or not" (Schultz, 1998). The indicators that used is the five basic indicators (Kotler, 2012), those are advertising, public relations and publicity, events and experiences, direct and interactive marketing, and word-of-mouth marketing.

City branding can be said as a strategy of a country or region to create a strong positioning in the minds of their target markets, such as product or service positioning, so a place includes a country, region, or city that can be widely known throughout the world. City branding can be interpreted as the process of forming a city brand or place to be known by the target market such as investors, tourists, talents, and events by using icons, slogans, exhibitions, and good positioning in various promotional media (Setianti, Dida, \& Putri, 2018). City branding is a strategy from a country, region, or city to get a strong position and can be widely known. In simple terms, City Branding, can be defined as identity in the form of symbols, logos, and brands that are attached to a city or a place Anholt as cited in (Moilanen \& Rainisto, 2009). While based on Anholt (2006) there are six aspects in measuring the effectiveness of city branding, which is: presence, potential, place, pulse, people, and prerequisites.

Grabow as cited in Kavaratzis (2004), concluding, the most important factor in urban marketing is functional communication, and 'communicative city competence are key factors and vital requirements for all successful urban marketing phases'. The City communicative competence is the goal and outcome of the city branding process. Kavaratzis (2004) which states that city branding is the right way to describe and implement city marketing. The city marketing application is highly dependent on construction, communication, and city image management.

\section{H3: Brand communication has influence City Branding.}

Brand equity is a set of assets (and liabilities) associated with brand names and symbols that add the value given by a product or service to the company and/or company customers (Aaker as cited in (Wilson, Ouyang, Rineha, \& Grant, 2004)). Brand equity is the added value given to products and services. Brand equity can be reflected in the way consumers think, feel, and act in relation to the brand, and also the price, market share, and profitability that the brand gives to the company (Kotler \& Keller, 2009). Aaker and Joachimsthaler as cited in (Blain et al., 2005), according to them, the brand equity theory consists of four main factors, namely: brand awareness; brand association; perceived 
quality; and brand loyalty.

The most accepted definition of consumer-based brand equity arises when consumers are familiar with brands and hold strong, profitable, and unique brand associations in their memories (Keller, 1993), therefore to obtain strong Brand Equity must be unique that distinguishes them from brands another, one strategy is the Unique Selling Proposition. Krishnan (1996) empirically shows that the characteristics of the association are such as the number of associations, valence, and uniqueness underlying the consumer. According to him, a unique selling proposition has become commonly used in terms of brand management when positioning brands.

\section{H4: USP has influence Brand Equity.}

Changes in brand knowledge structure can also show the effectiveness of communication. Communication can build brand equity. Brand awareness and brand image are two important elements of brand knowledge. One of the advantages of communication is the ability to reach consumers because they seek information and in this way expand brand awareness, help create profitable associations and encourage decisions to buy and cause a feeling of the long-lasting brand (Zailskaite-Jakste \& Kuvykaitė, 2013). Brand communication has a positive impact on the dimensions of brand equity, namely brand awareness, brand association, brand loyalty, and perceived quality. So, it can be concluded that brand communication will affect brand equity (Schivinski \& Dabrowski, 2015). Brand communication is a key element in managing the relationship between brands and stakeholders, including government regulators, and society. Brand communication must aim to increase brand loyalty by making consumers more tied to a brand to strengthen the relationship between brands and consumers over time (Pearson and Duncan and Moriarty, as cited in (Zehir et al., 2011).

Brand equity is an integral part of the branding process that occurs when consumers have a high level of awareness and familiarity with brands and hold strong, profitable and unique brand associations in memory (Keller, 1993). The concept of branding now extends to geographical locations. Brand places such as cities also involve building brand equity (Go \& Govers, 2000). Places, including countries and cities, have begun to implement branding strategies to improve their position as tourist destinations and attract targeted immigrants. A brand that has economic value is determined by the presence of brand equity. Measurement of brand equity thus becomes more quantitative based on the selective nature of place branding (Chan, 2014), in this study, what is meant by place branding is city branding. Strong identity has been shown to increase one's preference for some brands (Taufiq, Mandasari, Soeady, Ardiani, \& Rudiana, 2018), where identity is the main factor that complements the city's branding strategy, besides the creation of brand preferences, also reflects the presence of good brand equity.

\section{H5: Brand Communication has influence Brand Equity.}

H6: City Branding has influence Brand Equity.

From the above explanation, a research model can be formed as follows:

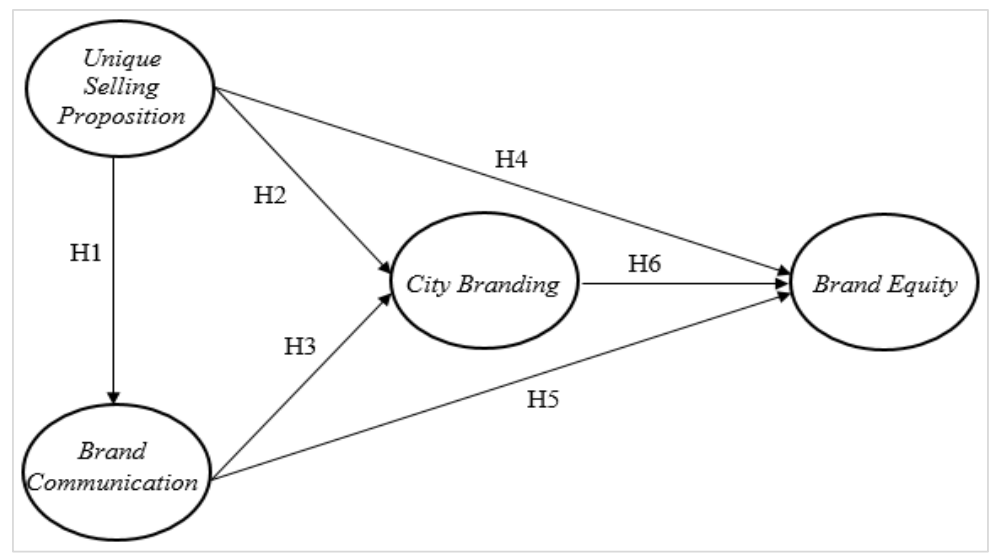

Figure 1 Research Model 


\section{METHODOLOGY}

The research carried out, included how the Unique Selling Proposition (USP) in Brand Communication and City Branding of Tasikmalaya as a City of Crafts to build the Brand Equity of this city, this research was conducted on the people of Tasikmalaya and in this study the researcher will use the Purposive Sampling technique where the sample used is native to the City of Tasikmalaya or who have stayed at least two years in this city and at least 18 years old also understand about the crafts owned by Tasikmalaya. The interval scale used in this study is a bipolar adjective, which is a refinement of the semantic scale in the hope that the resulting response can be intervally scaled data (Ferdinand, 2006). The scale used in the range 1-10. The usage of a scale of 1-10 (even scale) to avoid respondents' answers who tend to choose the answer in the middle. The sample in this study were 265 respondents who had met the minimum sample for SEM analysis. To analyze the effect of USP on brand communication and city branding that will build brand equity in this study using SEM. SEM is described as an analysis that combines a factor analysis approach (factor analysis), a structural model, and path analysis (Sugiyono, 2016).

\section{RESULTS AND DISCUSSION}

This research used 265 respondents that they consist of 148 the native of the city and 117 are not, but they have been living here in this city since two years ago. Thus, it is just to make the respondents at least knowing how the city is. The respondent's identity for this research is dominated by a female about $58.1 \%$, while the characteristic of their age is between 18 up to 23 years old has $78.1 \%$, and based on their occupation is dominated by students about $67.5 \%$.

Based on the results of testing on the five indicators of the variable, unique selling proposition shows good results. This can be interpreted that a city must have uniqueness and characteristics that can distinguish it from other cities. From the results of the questionnaire, it can be concluded that the unique selling proposition has an important role for the city in order to have a unique attraction that can distinguish it from other cities, the uniqueness is in the craft industry which becomes a potential opportunity for regional development in various fields such as tourism and the economy. From the five indicators, brand communication gets a good category. It can be concluded that Tasikmalaya has made a good effort to introduce its city so that it can be widely known as the City of Crafts. Organizing events such as the Tasik October Festival is one of the right steps taken by the government to introduce its craft wider. From the six indicators for measuring city branding, this variable gets a good category. It can be concluded that craft is a characteristic that belongs to Tasikmalaya, so this city is known as the City of Crafts. This city has positioned itself as the City of the craft by placing a number of unique craft ornaments in several locations, and there are craft centers typical of the City of Tasikmalaya. From the four indicators, it can be concluded that the variable brand equity is in a good category. Therefore, it can be concluded that the citizens of Tasikmalaya have realized and recognized this city as a City Crafts, as well as their crafts that have added value to the City.

To know the influence of unique selling proposition towards brand communication, city branding, and brand equity, it is analyzed by using SEM that processed by AMOS 23 program. The normal evaluation is obtained from the multivariate kurtosis value is 4.747 with the value of c.r 1.245 , which is in the range of $-2.58-2.58$ so it can be concluded that the data distributed normally. The result of this analysis of Z-score shows that there is no value higher than 3 , and the minimum value is -2.94851 then the maximum is 2,79393 , so there is no univariate outlier here. The output shows a range of maximum Mahalanobis is $35,438<X^{2}(45,31475)$, and there is no multivariate outlier found here so that the research can be continued.

On USP or unique selling proposition variable, there are five indicators that have standard loading $>0.5$ so that it can be said the indicator used is valid and can be used for measuring USP with the smallest standard loading: attractiveness about 0.564 and for Compatibility is 0.607 , and the rest of indicators is ideal because they have standard loading > 0.7. Then, brand communication variable from five indicators above, one indicator has an ideal validity, that direct marketing with its standard loading is 0.758 while the four others have enough validity level. Next to city branding variable, there are 4 from 6 indicators that have enough validity level with its standard loading $>0.5$ and two others, people and prerequisites have standard loading $>0.7$, so, it is on ideal validity level. While brand equity variable, 4 indicators used for measuring, all are having standard loading $>0.7$ and it's on ideal validity, and brand perceived quality has the highest standard loading, that is 0.854 .

Continue to reliability test; there are two tests: construct reliability and variance extract. Based on the result of construct reliability, data shown is reliable because it gets more than 0.07 and the smallest shown in brand communication about 0.839 . While variance extract also all variable that has variance extract on the condition is more 
Table 1 VALIDITY AND RELIABILITY

\begin{tabular}{|c|c|c|c|c|}
\hline Variable & Measurement & $\begin{array}{l}\text { Standard } \\
\text { Loading }\end{array}$ & $\begin{array}{l}\text { Construct } \\
\text { Reliability }\end{array}$ & $\begin{array}{l}\text { Variance } \\
\text { Extracted }\end{array}$ \\
\hline Unique Selling & - Favorable for potential society & 0.714 & 0.880 & 0.598 \\
\hline & $\begin{array}{l}\text { - Credible and believable } \\
\text { - Uniqueness and distinctiveness } \\
\text { - Compatible with community experience and expectations. } \\
\text { - Attractive and appealing to the communities and stakeholder. }\end{array}$ & $\begin{array}{l}0.751 \\
0.775 \\
0.608 \\
0.564\end{array}$ & & \\
\hline $\begin{array}{l}\text { Brand Communi- } \\
\text { cation }\end{array}$ & $\begin{array}{l}\text { - Good message visualization. } \\
\text { - Program design to create interaction, } \\
\text { - Good relations with various communities. } \\
\text { - Direct channel to reach out to the community and stakeholders. } \\
\text { - Aspects of communication between. }\end{array}$ & $\begin{array}{l}0.603 \\
0.578 \\
0.758 \\
0.628 \\
0.559\end{array}$ & 0.839 & 0.514 \\
\hline City Branding & $\begin{array}{l}\text { - The existence of city branding } \\
\text { - Economic and educational potential opportunities. } \\
\text { - Society perceptions of the physical aspects of a city. } \\
\text { - The appeal of a vibrant urban lifestyle. } \\
\text { - Characteristics of resident behavior. } \\
\text { - Basic quality of the city. }\end{array}$ & $\begin{array}{l}0.686 \\
0.633 \\
0.664 \\
0.652 \\
0.775 \\
0.785\end{array}$ & 0.907 & 0.621 \\
\hline Brand Equity & $\begin{array}{l}\text { - Level of recognition and recall of a brand. } \\
\text { - The impression that appears is related to the memory of the brand. }\end{array}$ & $\begin{array}{l}0.704 \\
0.854\end{array}$ & 0.911 & 0.720 \\
\hline
\end{tabular}

than 0.5 , where the smallest value is the brand community that has 0.514 .

The result of the analysis shows the data indicate that the value of the covariance matrix determinant of the sample is $4.44 \mathrm{e}-6>0$. It means that the data used in this study are feasible because there are no multicollinearity and singularity. For the residual analysis from the output of this study, none of the values of the Standardized Residual Covariances found outside the range -2.58 to 2.58 . So this model does not require significant modifications.

The result of this analysis can be seen in Figure 2 below:

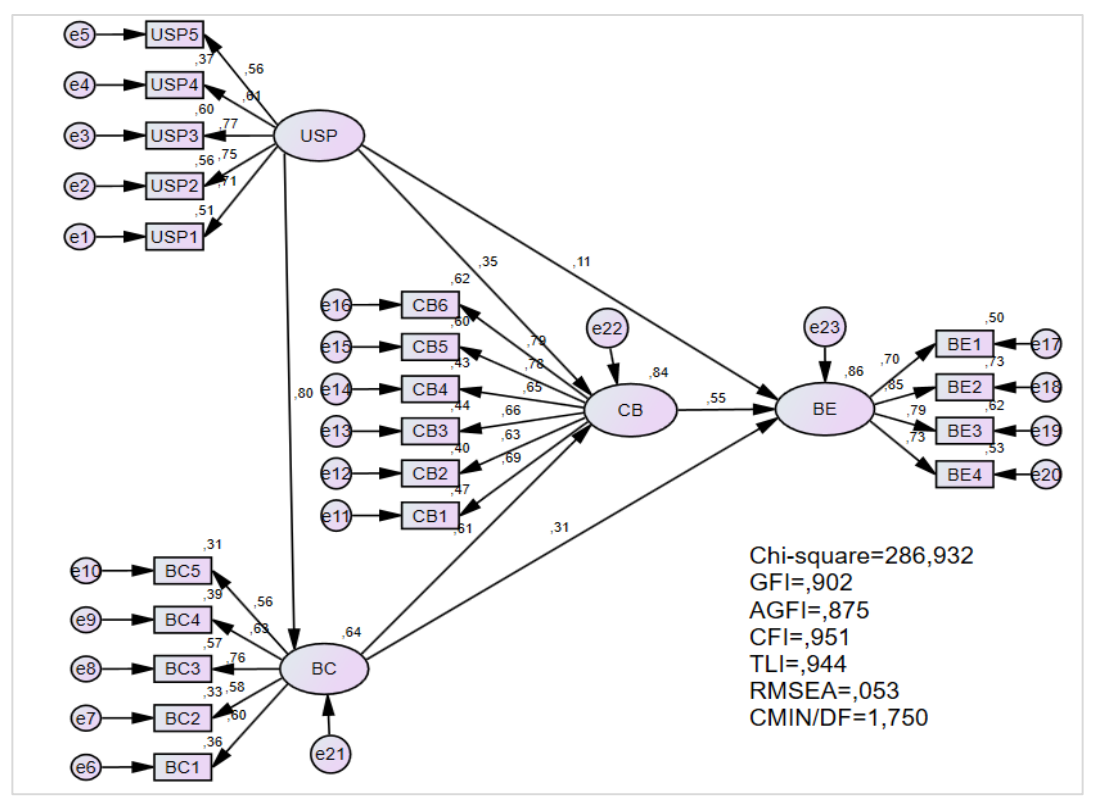

Figure 2 The result of Full Model of Structural Equation Modelling test

According to the result, RMSEA $0.053 \leq 0.08$ and CMIN / DF $1.750 \leq 2.00$, GFI $0.902 \geq 0.90$, and CFI $0.951 \geq$ 
0.95, which means that the testing conditions are acceptable though the other terms are marginally accepted such as for probability, AGFI, and TLI. Stick to what was stated by (Hair, Anderson, Babin, \& Black, 2010), that from several model feasibility tests, the model is said to be feasible if at least one of the model feasibility test is met. Then, it can be concluded that the model can be accepted and research can be continued without any modification or adjustment to the model. The value of the significance level for testing the hypothesis that has been determined in this study is $\alpha=$ 0.05 . The research hypothesis is accepted if the probability value $(p) \leq \alpha=0.05$. Based on the results of the study, it is obtained the information on the results of testing the hypothesis as follows:

The first hypothesis in this study suggests that a unique selling proposition or USP has a significant effect on brand communication, so testing is conducted. Through statistical calculations using AMOS SEM version 23, it is known that the effect of the USP on brand communication is C.R. amounting to 7.940 with $p 0.000 \leq 0.05$ so $\mathrm{H} 0$ is rejected, and $\mathrm{H} 1$ is accepted. It means that there is a significant effect between the unique selling proposition or USP towards brand communication. The better USP reflected by favorability, believability, distinctiveness, compatibility, and attractiveness will have a good impact on brand communication. Thus, if consumers (City Residents) think that USP depicts favorability, believability, distinctiveness, compatibility, and attractiveness, then consumers will give high weight and vice versa, because of the weight given, the greater the impact of USP on the success of communication output (Niu \& Wang, 2016).

The second hypothesis in this research thought that USP has a significant influence on City Branding, so the test is done. Through statistic calculation, SEM AMOS version 23 shows that the influence between USP towards City Branding got C.R value about 3,163 with $p 0.002 \leq 0.05$, so $\mathrm{H} 0$ is rejected, and $\mathrm{H} 2$ is accepted. It means that there is significant influence between USP towards city branding. A good USP will be able to strengthen city branding because it will give a specific impression about the identity of the city. Thus, the existence of USP from a place, destination, city, or country will increase the branding of the place (Blain et al., 2005).

The third hypothesis also thought brand communication could give significant influence towards city branding of this city of crafts. Through statistic calculation, SEM AMOS version 23 shows that the influence between brand communication towards City Branding got C.R value about 4.774 with $p 0.000 \leq 0.05$ so $\mathrm{H} 0$ is rejected, and $\mathrm{H} 3$ is accepted. It means that there is significant influence from brand communication towards city branding. The formation of city branding will depend on how the city communicates its values. Therefore, the existence of good communication will increase city branding because the marketing of a city is very dependent on the communication and management of the city (Kavaratzis, 2004).

The fourth hypothesis also thought that USP could give significant influence towards brand equity of this city of crafts. Through statistic calculation, SEM AMOS version 23 shows that the influence between USP towards brand equity got C.R value about 1.053 with $p 0.292 \geq 0.05$ so $\mathrm{H} 4$ is rejected, and $\mathrm{H} 0$ is accepted. It means that there is no influence from USP towards brand equity. Good or not USP, not proven to have an impact on strengthening a city's brand equity. Companies are wrong when they assume that they only need to offer something unique to attract business, but there are other elements such as price, availability, and familiarity that also play an important role (Schmid, 2017).

Then, the fifth hypothesis also thought that brand communication could give significant influence towards brand equity of this city of crafts. Through statistic calculation, SEM AMOS version 23 shows that the influence between brand communication towards brand equity got C.R value about 1.963 with $p 0.050 \leq 0.05$ so H0 is rejected, and H5 is accepted. It means that there is significant influence from brand communication towards brand equity because $p$ is equal with 0.05 so there is the test through $t$ table which $t$ is obtained as much as 1.650735 that means C.R $\geq t$ table and can make $\mathrm{H} 1$ to be accepted. The better brand communication formed by advertising, public relations and publicity, events and experiences, direct and interactive marketing, and word-of-mouth marketing will increase brand equity in a city. When communication is managed correctly, it will form profitable brand equity (Zailskaite-Jakste \& Kuvykaite, 2013).

The last one, the sixth hypothesis also thought that city branding could give significant influence towards brand equity of this city of crafts. Through statistic calculation, SEM AMOS version 23 shows that the influence between city branding towards brand equity got C.R value about 3.237 with $p 0.001 \leq 0.05$ so $\mathrm{H} 0$ is rejected, and $\mathrm{H} 6$ is accepted. It means that there is a significant influence from city branding towards brand equity. The better the city branding, the stronger the brand equity. The concept of branding that is applied to places such as cities, countries, and other geographical locations will build brand equity (Go \& Govers, 2000). 


\section{CONCLUSION}

Based on the finding and discussion above, it showed that USP or unique selling proposition has influence brand communication. It means when the USP strategy is done perfectly, which it can increase brand communication. Then, USP also proved that it has a significant influence on city branding. So it can be concluded that better USP will increase City Branding. Besides, brand communication also proved that it has a significant influence on city branding. So, the better brand of a city is communicated, so the increasing of city branding also will be better, because by communicating what is owned by a city such as holding an event, advertising, public relations, direct marketing, and word of mouth marketing will make what is owned by a city will be known to increase the quality of branding. The However, in this study, USP still did not prove that it has influence towards brand equity so that it can be said that USP still was not able to build strong brand equity in the city, because if the uniqueness in the Unique Selling Proportion is not communicated it will not make the stakeholders aware that they will not even make it loyal. Unique selling proposition has not been able to build brand loyalty. While brand communication and city branding were proven. So, the better brand communication and city branding from a city, the higher brand equity of the city.

The contribution and value of this research are to observe the brand equity of a city through city branding with the USP approach, which is also applied to brand communication. This study provides empirical evidence when the uniqueness of a city is not communicated and applied to city branding, it will not be able to build brand equity significantly. Therefore, the model offered in this study can be done effectively. This study fulfills the objective because this study describes the direction of how a USP strategy must be designed and applied to brand communication and city branding of a city to create strong brand equity and will be a competitive advantage for the city. Brand equity can create advantages and benefits for the firm, the trade, or the consumer (Tuominen, 1999).

\section{THE LIMITATIONS AND FUTURE RESEARCH}

This research exactly has a limitation which the result showed between USP and brand equity did not show the significant influence. This can be a reference for further research by adding other variables besides the USP variable to be used as a variable that will build brand equity in a city. In addition, in this study, brand communication also has a small effect on influencing brand equity, therefore further research can add other variables in mediating exogenous with endogenous variables in this study, for example, brand differentiation where differences from a brand and another will increase city branding from a city and increase the strong brand equity of the city. In addition to building city branding, a deeper analysis of the condition of the community in the city is needed. Such as entering the Self-congruity variable as a variable that will determine the suitability between the self-concept of city residents and the branding that the city has. Because city residents are the most important component in building the city, residents are an integrated part of a

place brand. Their characteristics, behavior, and reputation could make a city more attractive to visitors, new residents, investors, and companies (Braun, Kavaratzis, \& Zenker, 2013).

\section{REFERENCES}

Anholt, S. (2006). The Anholt-GMI city brands index: How the world sees the world's cities. Place Branding, 2(1), 18-31. doi:https://doi.org/10.1057/palgrave.pb.5990042

Ashworth, G. J., \& Voogd, H. (1988). Marketing the city: Concepts, processes and Dutch applications. Town Planning Review, 59(1), 65-79. doi:https://doi.org/10.3828/tpr.59.1.9t614v1537652w31

Blain, C., Levy, S. E., \& Ritchie, J. B. (2005). Destination branding: Insights and practices from destination management organizations. Journal of Travel Research, 43(4), 328-338. doi:https://doi.org/10.1177/0047287505274646

Boisen, M., Terlouw, K., \& van Gorp, B. (2011). The selective nature of place branding and the layering of spatial identities. Journal of Place Management and Development, 4(2), 135-147. doi:https://doi.org/10.1108/ 17538331111153151

Borseková, K., Vaňová, A., \& Petríková, K. (2015). From tourism space to a unique tourism place through a conceptual approach to building a competitive advantage. In Marketing places and spaces (pp. 155-172). New York, NY: Emerald Group Publishing Limited. doi:https://doi.org/10.1108/s1871-317320150000010012

Braun, E., Kavaratzis, M., \& Zenker, S. (2013). My city-my brand: The role of residents in place branding. Journal of Place Management and Development, 6(1), 18-28. doi:https://doi.org/10.1108/17538331311306087 
Chan, C.-s. (2014). Applying linear programming in city brand equity concept: A case study of Hong Kong. International Journal of Tourism Sciences, 14(1), 1-22. doi:https://doi.org/10.1080/15980634.2014.11434682

Dinnie, K. (2010). City branding: Theory and cases. New York, NY: Springer.

Elegbe, O., \& Adesanoye, O. (2017). Promoting brand loyalty through advertising campaign: Qualitative study of Nigerian breweries maltina product. Review of Communications and Media Studies, 1(4), 1-15.

Eze, I. O. (2017). Corporate governance mechanisms and earnings management in Nigerian food product companies. Journal of Administrative and Business Studies, 3(1), 1-9. doi:https://doi.org/10.20474/jabs-3.1.1

Ferdinand, A. (2006). Management research methods: Research guidelines for thesis. Unpublished master's thesis, Diponegoro University, Semarang, Indonesia.

Go, F. M., \& Govers, R. (2000). Integrated quality management for tourist destinations: A European perspective on achieving competitiveness. Tourism Management, 21(1), 79-88. doi:https://doi.org/10.1016/s0261-5177(99) 00098-9

Hair, J. F., Anderson, R. E., Babin, B. J., \& Black, W. C. (2010). Multivariate data analysis: A global perspective (vol. 7). Upper Saddle River, NJ: Pearson.

Hung, C., Ching, \& Chen, I. C. (2017). A study on the luxury goods counterfeiting in the view of the infringement on design authenticity. International Journal of Business and Economic Affairs, 2(6), 341-345. doi:https://doi.org/ 10.24088/ijbea-2017-26003

Kavaratzis, M. (2004). From city marketing to city branding: Towards a theoretical framework for developing city brands. Place Branding, 1(1), 58-73. doi:https://doi.org/10.1057/palgrave.pb.5990005

Kavaratzis, M., \& Ashworth, G. J. (2005). City branding: An effective assertion of identity or a transitory marketing trick? Tijdschrift Voor Economische en Sociale Geografie, 96(5), 506-514. doi:https://doi.org/10.1057/ palgrave.pb.5990056

Keller, K. L. (1993). Conceptualizing, measuring, and managing customer-based brand equity. Journal of Marketing, 57(1), 1-22. doi:https://doi.org/10.2307/1252054

Kotler, P. (2012). Marketing management. Upper Saddle River, NJ: Pearson Prentice Hall.

Kotler, P., \& Keller, K. (2009). Marketing management. Upper Saddle River, NJ: Pearson Prentice Hall.

Krishnan, H. S. (1996). Characteristics of memory associations: A consumer-based brand equity perspective. International Journal of research in Marketing, 13(4), 389-405. doi:https://doi.org/10.1016/s0167-8116(96) 00021-3

Kuada, J. (2016). Editorial. African Journal of Economic and Management Studies, 7(3), 290-294. doi:https://doi.org/ 10.1108/AJEMS-06-2016-0088

Moilanen, T., \& Rainisto, S. (2009). How to brand nations, cities and destinations. In A planning book for place branding. London, UK: Palgrave Macmillan. doi:https://doi.org/10.1057/9780230584594

Nasution, R. A., \& Ardin, I. (2010). Consumer perceived value analysis of new \& incumbent brands of Gudang Garam \& Sampoerna. The Asian Journal of Technology Management, 3(1), 16-30.

Niu, Y., \& Wang, C. L. (2016). Revised unique selling proposition: Scale development, validation, and application. Journal of Promotion Management, 22(6), 874-896. doi:https://doi.org/10.1080/10496491.2016.1214209

Oetomo, H. W., \& Budiyanto. (2017). Brand image as mediation effect of experiential marketing and differentiation product to the buying decision of Toyota cars. International Journal of Business and Administrative Studies, 3(5), 175-182. doi:https://doi.org/10.20469/ijbas.3.10003-5

Olajide, T. F., \& Abubakri, O. R. (2012). Making slogans and Unique Selling Propositions (USP) beneficial to advertisers and the consumers. New Media and Mass Communication, 3, 30-35.

Richards, G. (2014). Creativity and tourism in the city. Current Issues in Tourism, 17(2), 119-144. doi:https://doi.org/ $10.1080 / 13683500.2013 .783794$

Schivinski, B., \& Dabrowski, D. (2015). The impact of brand communication on brand equity through facebook. Journal of Research in Interactive Marketing, 9(1), 31-53. doi:https://doi.org/10.1108/jrim-02-2014-0007

Schmid, F. (2017). The effect of sport sponsorship on brand equity: Does the sponsorship of usain bold help puma to increase their brand equity? Bachelor's thesis, Hame University of Applied Sciences, Hameenlinna, Finland.

Schultz, D. E. (1998). Determining how brand communication works in the short and long terms. International Journal of Advertising, 17(4), 403-426. doi:https://doi.org/10.1080/02650487.1998.11104730 
Setianti, Y., Dida, S., \& Putri, N. P. C. U. (2018). City branding of denpasar city as a creative city through the denpasar festival event. In Proceedings of MICoMS 2017 (pp. 367-371). Lhokseumawe, Indonesia: Emerald Publishing Limited. doi:https://doi.org/10.1108/978-1-78756-793-1-00025

Sugiyono. (2016). Understanding qualitative research. Bandung, Indonesia: Alfabeta.

Taufiq, A. R., Mandasari, A. E., Soeady, M. S., Ardiani, G. T., \& Rudiana, D. (2018). Millenial muslim preference: Status or culture. In Airlangga International Conference on Economic and Business. Surabaya, Indonesia.

Tuominen, P. (1999). Managing brand equity. Retrieved from https://bit.ly/2LHfiL6

Van Gelder, S. (2008). An introduction to city branding. Placebrands Ltd, 1(04), 1-5.

Wichailert, K., \& Yousapornpaiboon, K. (2017). Brand equity affects brand loyalty of the bottled mineral drinking water in Thailand. Journal of Administrative and Business Studies, 3(4), 180-191. doi:https://doi.org/10.20474/ jabs-3.4.3

Wilson, W., Ouyang, M., Rineha, S. M., \& Grant, E. S. (2004). Brand equity in the drinkin'box market: Canadian vs. American. Journal of Comparative International Management, 8(1), 55-65.

Zailskaite-Jakste, L., \& Kuvykaitè, R. (2013). Communication in social media for brand equity building. Economics and Management, 18(1), 142-153. doi:https://doi.org/10.5755/j01.em.18.1.4163

Zehir, C., Şahin, A., Kitapçı, H., \& Özşahin, M. (2011). The effects of brand communication and service quality in building brand loyalty through brand trust; the empirical research on global brands. Procedia-Social and Behavioral Sciences, 24, 1218-1231. doi:https://doi.org/10.1016/j.sbspro.2011.09.142 